\title{
PEMULIHAN EKONOMI MELALUI PENDAMPINGAN LAPORAN KEUANGAN UMKM WILAYAH GUNUNG ANYAR SURABAYA
}

\author{
Halimatus Sa'diyah \\ Universitas Muhammadiyah Surabaya \\ halimatus@fe.um-surabaya.ac.id
}

Submitted : 1 Oktober 2021 Accepted: 24 Desember 2021

Published : 31 Desember 2021

Abstrak Kehadiran pencatatan dalam islam pada dasarnya adalah untuk memastikan setiap denyut dan napas ekonomi dijalankan serta membuat masyarakat menjadi semakin beriman dan bertakwa, sehingga Allah SWT akan menurunkan kebaikan bagi kehidupan manusia (berkah). Keberkahan suatu usaha dilandasi dengan menerapkan nilai - nilai ekonomi is lam dalam menjalankan usahanya dan di aplikasikan dalam bentuk pencatatan setiap transaksiusaha. Tujuan pengabdian dalampenerapan akuntansimempunyai peranan yang sangat penting dalam mengembangkan Usaha Mikro Kecil dan Menengah, tanpa adanya laporan keuangan para pelaku usaha tidak dapat mengetahui secara persis berapa pendapatan, pengeluaran dan berapa laba usaha. Pengabdian ini menggunakan pendekatan kualitatif dengan jenis pengabdian fenomenologi. Teknik pengumpulan data menggunakan teknik dokumentasi yang merupakan cara yang penulis lakukan untuk mengumpulkan data dari berbagai sumber referensi. Hasil pengabdian memandang penerapan pencatatan akuntansi bukan suatu kewajiban yang harus dilaksanakan dalam kegiatan usaha karena hal yang penting menurut pelaku UMKM ialah dapat bertahan dimasa pemulihan ekonomi saat ini dengan tetap memperoleh laba.

Kata Kunci: Pemulihan Ekonomi, Laporan Keuangan, UMKM 


\section{PENDAHULUAN}

Pemulihan ekonomi menjadi tanggungjawab pemerintah untuk berkomitmen terus memperkuat Usaha Mikro, Kecil, dan Menengah (UMKM) untuk segera pulih dari imbas pandemi COVID-19. Melalui Insentif pemulihan ekonomi nasional (PEN), Banpres Tunai, Digitalisasi UMKM, dan Akses Permodalan dengan KUR menjadi bentuk nyata kehadiran pemerintah dalam mendorong pemulihan dan pemberdayaan UMKM. Harapan pemerintah UMKM bisa tumbuh dan berkembang dimasa pemulihan ekonomi. Sebagai masyarakat yang mayoritas Islam diwajibkan untuk berusaha dalam keadaan sesulit apapun.

"Dan Allah melebihkan sebagian kamu atas sebagian yang lain dalam hal rezeki, tetapi orang yang dilebihkan (rezekinya itu) tidak mau memberikan rezekinya kepada para hamba sahaya yang mereka miliki, sehingga mereka sama - sama (merasakan) rezeki itu. Mengapa mereka mengingkari nikmat Allah?". (Surah an-Nahl ayat 71)

Ayat di atas memberikan pelajaran bagi kita bahwa setiap hamba sahaya sudah diberikan takaran rezeki, tergantung bagaimana usaha yang dilakukan untuk memperoleh rezeki.
Kehadiran pencatatan dalam islam pada dasarnya adalah untuk memastikan setiap denyut dan napas ekonomi dijalankan serta membuat masyarakat menjadi semakin beriman dan bertakwa, sehingga Allah SWT akan menurunkan kebaikan bagi kehidupan manusia (berkah)(Novalien Carolina Lewaherilla et al., 2021). Kerberkahan suatu usaha dilandasi dengan menerapkan nilai nilai ekonomi islam dalam menjalankan usahanya dan di aplikasikan dalam bentuk pencatatan setiap transaksi usaha. Seperti halnya Usaha Mikro, Kecil, dan Menengah (UMKM) merupakan salah satu bidang usaha yang dapat berkembang dan konsisten dalam perekonomian nasional.

UMKM menjadi wadah yang baik bagi masyarakat dengan kondisi pemulihan ekonomi saat ini, karena tercipta lapangan pekerjaan yang produktif. Perkembangan usaha kecil saat ini mengalami kondisi yang cukup memprihatinkan. Kondisi yang terjadi pada saat pemulihan ekonomi membuat sektor ekonomi dan usaha kecil begitu terpuruk. Banyak pelaku usaha mikro, kecil, dan menengah (UMKM) diperhadapkan dengan keadaan resesi ekonomi yang juga menghambat 
kemajuan usahanya bahkan kedapatan banyak yang gulung tikar (Hastuti, 2021). Pendapatan yang diterima menurun akibat berkurangnya pelanggan sejak diberlakukannya PPKM. Hingga saat ini, situasi semakin merugikan pelaku UMKM, tanpa ada solusi pasti dari pemerintah.

\section{Pandemi memberikan dampak} yang besar terhadap berbagai bidang perekonomian, termasuk usaha mikro kecil dan menengah (UMKM) di daerah Gunung Anyar . Apalagi saat ini akses UMKM masih rentan dan terbatas. Dan ditambah adanya kebijakan pembatasan social karena pandemi. Hal ini menyebabkan tidak sedikit UMKM yang juga terdampak dan mengalami penurunan produktivitas. Pada saat yang sama, usaha mikro, kecil, dan menengah telah memberikan kontribusi yang signifikan terhadap lapangan kerja. Terutama di masa krisis seperti ini banyak yang membutuhkan pekerjaan.

Informasi dari Kemenkop UKM ada sekitar 37.000 UMKM yang memberikan laporan bahwa mereka terdampak serius dengan adanya pandemic ini di tandai dengan sekitar $56 \%$ melaporkan terjadinya penurunan penjualan, $22 \%$ persen melaporkan permasalah pada aspek pembiayaan,
$15 \%$ melaporkan terkendala dengan distribusi barang dan 4\%, melaporkan kesulitan mendapatkan bahan mentah. Berdasarkan hasil observasi yang dilakukan dalam pengabdian (Hardilawati, 2020) terhadap UMKM di daerah Pekanbaru (2020). Berdasarkan dari hasil observasi, rata-rata UMKM merasakan penurunan omset selama adanya pandemi. Hal ini terjadi karena mulai berkurangnya aktivitas yang dilakukan diluar rumah, kesulitan dalam memperoleh bahan baku karena terjadi kendala transportasi, serta mulai turunnya kepercayaan masyarakat terhadap produk yang dipasarkan secara online.

\section{Peran Akuntansi Bagi Usaha} Mikro, Kecil dan Menengah (UMKM) Akuntansi mempunyai peranan penting untuk mencapai keberhasilan usaha, termasuk bagi Usaha Mikro, Kecil dan Menengah (UMKM) dan informasi akuntansi dapat menjadi dasar yang akurat bagi pengambilan keputusan dalam pengelolaan usaha kecil dan menengah. Penyediaan informasi akuntansi bagi usaha kecil dan menengah juga diperlukan khususnya untuk akses subsidi pemerintah dan akses tambahan modal bagi Usaha Mikro, Kecil dan Menengah (UMKM) 
telah diatur dalam Undang-Undang Republik Indonesia No. 7 tahun 2021 Tentang Usaha Mikro, Kecil dan Menengah. Laporan keuangan Usaha Mikro Kecil dan Menengah (UMKM) adalah pembukuan sederhana yang dibuat oleh pemilik Usaha untuk mengetahui apakah bisnis yang dikelola menguntungkan atau merugikan. Tujuan pengabdian ini adalah dalam penerapan akuntansi mempunyai peranan yang sangat penting dalam mengembangkan Usaha Mikro Kecil dan Menengah, tanpa adanya laporan keuangan para pelaku usaha tidak dapat mengetahui secara persis berapa pendapatan, pengeluaran dan berapa laba usaha. Kalaupun ada perencenaan biasanya tidak tersusun secara rapi dan tertib. Permasalah ini semakin kompleks seiring dengan bertambah besarnya kegiatan usaha. Dalam menyusun laporan keuangan sebaiknya Usaha Mikro, Kecil dan Menengah (UMKM) harus disiplin dalam melakukan pencatatan setiap transaksi dalam jurnal atau laporan keuangan, lalu mendokumentasikan setiap bukti-bukti transaksi sehingga mempermudah dalam proses pencatatan keuangan. (Widjaja, 2018) dalam (Mulyani et al., 2019)

\section{TINJAUAN PUSTAKA}

Definisi Usaha Mikro, Kecil dan Menengah (UMKM) menurut UndangUndang Republik Indonesia Nomor 7 Tahun 2021:(Pemerintah et al., 2021)

a. Usaha Mikro adalah usaha produktif milik orang perorangan dan atau badan usaha perorang yang rnemenuhi kriteria Usaha Mikro sebagaimana diatur dalam Peraturan Pemerintah ini.

b. Usaha Kecil adalah usaha ekonomi produktif yang berdiri sendiri, yang ditakukan oleh orang perorangan atau badan usaha yang bukan merupakan anak perusahaan atau bukan cabang perusahaan yang dimiliki, dikuasai, atau menjadi bagian baik langsung maupun tidak langsung dari Usaha Menengah atau usaha besar yang memenuhi kriteria Usaha Kecil sebagaimana dimaksud dalam peraturan pemerintah ini.

c. Usaha Menengah adalah usaha ekonomi produktif yang berdiri sendiri, yang dilakukan oleh orang perorangan atau badan usaha yang bukan merupakan anak perusahaan atau cabang perusahaan yang dimiliki, dikuasai, atau rnenjadi bagian baik langsung maupun 
ticlak langsung dengan Usaha

Kecil atau usaha besar yang memenuhi kriteria Usaha

Menengah sebagaimana diatur dalam peraturan pemerintah ini.

Kriteria Usaha Mikro, Kecil dan Menengah (UMKM) menurut UU Nomor 7 tahun 2021 adalah sebagai berikut:

\section{Kriteria UMKM}

UMKM diklasifikasikan menurut kriteria modal usaha atau hasil penjualan tahunan. Modal usaha yakni modal sendiri dan modal pinjaman untuk melakukan aktivitas usaha.

2. Kekayaan Bersih/Modal Usaha

a. Usaha Mikro, paling banyak $\mathrm{Rp} 1$. $000.000 .000,00$

b. Usaha Kecil, lebih dari Rp 1. 000.000.000,00 - paling banyak Rp 5. $000.000 .000,00$

c. Usaha Menengah, lebih dari Rp. 5. 000.000.000,00 - paling banyak Rp. 10. 000.000.000,00. Diluar tanah dan bangunan tempat usaha.

3. Hasil Penjualan Tahunan

a. Usaha Mikro, paling banyak

Rp 1. 000.000.000,00

b. Usaha Kecil, lebih dari

$\mathrm{Rp}$ 2. $\quad 000.000 .000,00$ - paling banyak Rp 15. 000.000.000,00 c. Usaha Menengah, lebih dari

Rp. 15. 000.000.000,00 - paling banyak Rp. 50. 000.000.000,00.

Laporan Keuangan Menurut Hermanto dan Agung (2012:2) dalam (Wiyani et al., 2017) laporan keuangan merupakan suatu ringkasan transaksi yang dilakukan dari perusahaan yang terjadi selama satu periode akuntansi atau satu tahun buku. Laporan keuangan merupakan alat informasi yang menghubungkan perusahaan dengan pihak - pihak yang berkepentingan, yang menunjukan kondisi kesehatan keuangan perusahaan dan kinerja perusahaan. Berdasarkan definisi di atas, dapat disimpulkan laporan keuangan adalah hasil akhir dari proses akuntansi berupa informasi keuangan yang terdiri dari laporan posisi keuangan, laporan laba rugi, laporan perubahan ekuitas, laporan arus kas, catatan atas laporan keuangan yang digunakan oleh pihak -pihak yang berkepentingan untuk menilai kinerja dan kondisi ekonomi suatu usaha atau perusahaan.

Manfaat laporan akuntansi terhadap para pelaku UKM, antara lain:

1) UMKM dapat mengetahui kinerja keuangan perusahaan, 
2) UMKM dapat mengetahui, memilah, dan membedakan harta perusahaan dan harta pemilik,

3) UMKM dapat mengetahui posisi dana baik sumber maupun penggunaannya, (4) UMKM dapat membuat anggaran yang tepat,

5) UMKM dapat menghitung pajak,

6) UMKM dapat mengetahui aliran uang tunai selama periode tertentu, dan

7) dapat meyakinkan pihak lembaga keuangan dalam memberikan bantuan modal usaha bagi UMKM.

8) UMKM lebih mudah dalam pengambilan keputusan. (Surjono et al., 2021)

\section{METODE PELAKSAAN PENGABDIAN}

Pengabdian ini menggunakan pendekatan kualitatif dengan jenis fenomenologi. Menurut Creswell (2014:20) dalam (Kusumawardhany, 2020) fenomenologi merupakan strategi di mana mengidentifikasi fenomena berdasar pengalaman manusia terhadap suatu peristiwa tertentu. Pada pengabdian ini juga digunakan sudut pandang naratif dengan prosedur restoring, yaitu menceritakan kembali sesuai pengalaman seorang individu, di mana memulai dengan suatu peristiwa penting dalam kehidupan sang partisipan. Teknik pengumpulan data menggunakan teknik dokumetasi yang merupakan cara yang penulis lakukan untuk mengumpulkan data dari berbagai sumber referensi. Selain itu, karena keterbatasan waktu dan materi terkait pengabdian ini, penulis menggunakan telaah literatur (literature review) dan artikel pengabdian (research article), dari jurnal dan pemberitaan online yang bertujuan untuk membuat kesimpulan dan evaluasi pada permasalahan yang penulis kaji (Rosita, 2020)

\section{HASIL DAN PEMBAHASAN}

Narasumber pada pengabdian ini adalah $\mathrm{Bu}$ Nidah (42 tahun) seorang pelaku UMKM dibidang makanan Pia Enfina. Pia Enfina mulai berproduksi tahun 2009 sebagai langkah awal. Dapat dijelaskan bahwa pada awal membuka usaha, modal usaha dan uang pribadi sudah terpisah, sehingga pemilik usaha mengetahui secara pasti jumlah keluar masuknya uang untuk kegiatan usaha. Akan tetapi pencatatan yang dilakukan bu Nidah terbatas pencatatan uang belanja untuk produksi dan pemasukan dari hasil penjualan. Untuk itu UMKM dalam hal ini berpikir secara taktis yang penting tidak rugi dalam berjualan 
meskipun tanpa pencatatan. Para pelaku UMKM cenderung mengharapkan agar usaha segera jalan, sehingga dapat mendukung kesejahteraan pemilik karena adanya pemasukan dari hasil penjualan tanpa laporan keuangan.

Pendampingan dilakukan dengan beberapan tahapan:

a. Pemahaman tentang UMKM dan digitalisasi pengembangan UMKM

b. Strategi pemilihan produk unggulan.

c. Pendampingan perhitungan HPP.

d. Pendampingan pembuatan laporan keuangan.

Urusan administrasi bagi pelaku UMKM belum menjadi prioritas utama mengingat pengetahuan yang sangat terbatas mengenai laporan keuangan. Ada beberapa alasan yang menyebabkan tata administrasi usaha belum menjadi fokus para UMKM. Diantaranya, pelaku UMKM kerjanya serba merangkap. Merangkap sebagai pemilik, pengolah, marketing, dan keuangan praktis sehingga hasilnya tidak fokus. Penghitungan laba atau rugi dilakukan dengan ringkas dengan mencatat uang yang dibelanjakan sebagai modal dan pendapatan dari hasil penjualan. Secara sederhana pelaku menghitung laba dengan mengetahui selisih antara penjualan dengan biaya yang

dikeluarkan setiap produksi. Sejauh tidak ada peraturan dan pemeriksaan yang mewajibkan UMKM untuk membuat laporan keuangan, maka laporan keuangan jadi urusan "nanti saja". Jika ada keperluan yang mensyaratkan ada laporan keuangan, maka laporan keuangan akan dibuat oleh pelaku usaha.

Pembuatan laporan keuangan bukanlah kegiatan yang rutin karena keterbatasan waktu dan pengetahuan untuk menyusunnya sehingga bagi pemilik pencatatan kegiatan transaksi harian sudah cukup mewakili sebagai pengganti laporan keuangan. Selain itu, pencatatan yang dilakukan tidak menggunakan bahasa akuntansi, namun menggunakan istilah yang memudahkan pembuat dalam penyusunan jurnal. Pencatatan yang dilakukan meliputi pencatatan penjualan harian sebatas pencatatan pengeluaran dan pencatatan pemasukan. Seharusnya dalam dunia usaha makanan setidaknya ada kejelasan dalam penentuan harga pokok produksi, tidak hanya sekedar perhitungan praktis tanpa adanya pengolahan informasi.

Hal ini sesuai dengan paparan $\mathrm{Bu}$ Nidah, yaitu "saya tidak perlu membuat laporan keuangan mba, yang penting 
setiap harinya ada pendapatan dari hasil penjualan saja sudah cukup mbak." Secara umum pemilik UMKM memandang penerapan pencatatan akuntansi bukan suatu kewajiban yang harus dilaksanakan dalam kegiatan usaha karena hal yang penting menurut pelaku UMKM ialah dapat bertahan dimasa pemulihan ekonomi saat ini. Selain itu, laba yang diperoleh seringkali digunakan untuk keperluan pribadi tanpa ada pencatatan yang jelas terkait laporan keuangan. Banyaknya pemikiran tersebut menyebabkan pelaku UMKM seringkali menyebabkan tidak bertambah majunya kegiatan usaha yang dijalankan. Apabila pemilik berkeinginan melakukan pemisahan harta dan menerapkan akuntansi, pemilik akan lebih terbantu dalam mengetahui jumlah keseluruhan harta dan mengontrol kinerja usaha yang dilakukan. Dengan penerapan akuntansi juga akan membantu pemilik dalam mengambil keputusan. Keputusan yang diambil diharapkan dapat memberikan kontribusi bagi pelaku dalam mengembangkan usahanya sehingga dapat bertahan dan berkembang.

Hal ini mendukung pengabdian Savitri dan Saifudin (2018) dalam (Kusumawardhany, 2020) yang menjelaskan bahwa hasil pencatatan yang baik akan dapat digunakan sebagai dasar dalam pengambilan keputusan serta pengajuan kredit pada bank untuk mendapatkan penambahan modal. Sesuai dengan hasil pada pengabdian ini bahwa dengan pembuatan laporan keuangan, maka pengajuan kredit KUR pemilik UMKM diterima. Manfaat lain yang diterima pemilik UMKM ialah memberikan informasi yang tepat dalam pelaksanaan kegiatan usaha, serta dapat merancang langkah yang akan dilaksanakan guna memperkuat atau memperluas kegiatan operasi usaha yang ditekuni kedepannya.

Laporan keuangan yang dihasilkan dari pencatatan akuntansi sangat membantu pemilik UMKM dalam menganalisa perubahan struktur modal, keputusan investasi, perolehan pendapatan, pengeluaran biaya dan laba bersih yang dihasilkan dari kegiatan usaha yang telah berjalan. Dengan membandingkan laporan keungan dari tahun ke tahun, pemilik UMKM akan memperoleh informasi yang penting tentang apa yang sudah baik dan apa yang masih perlu diperbaiki. Alasan mengapa pentingnya laporan keuangan bagi UMKM, sebagai perencanaan bisnis, dapat mengetahui posisi 
keuangan setiap bulan, mudah dalam mengontrol biaya, mudah dalam mendapatkan pinjaman dari bank, untuk menghitung pajak yang harus dibayar dan sebagai informasi untuk manajemen dan alat pengambilan keputusan dalam bisnis. Keputusan dalam hal ini pelaku usaha bisa memutuskan apakah menambah atau mengurangi produksi setiap proses pembuatan Pia Enfina. Berikut proses produksi Pia Enfina dengan beberapa tahapan sampai proses dikemas
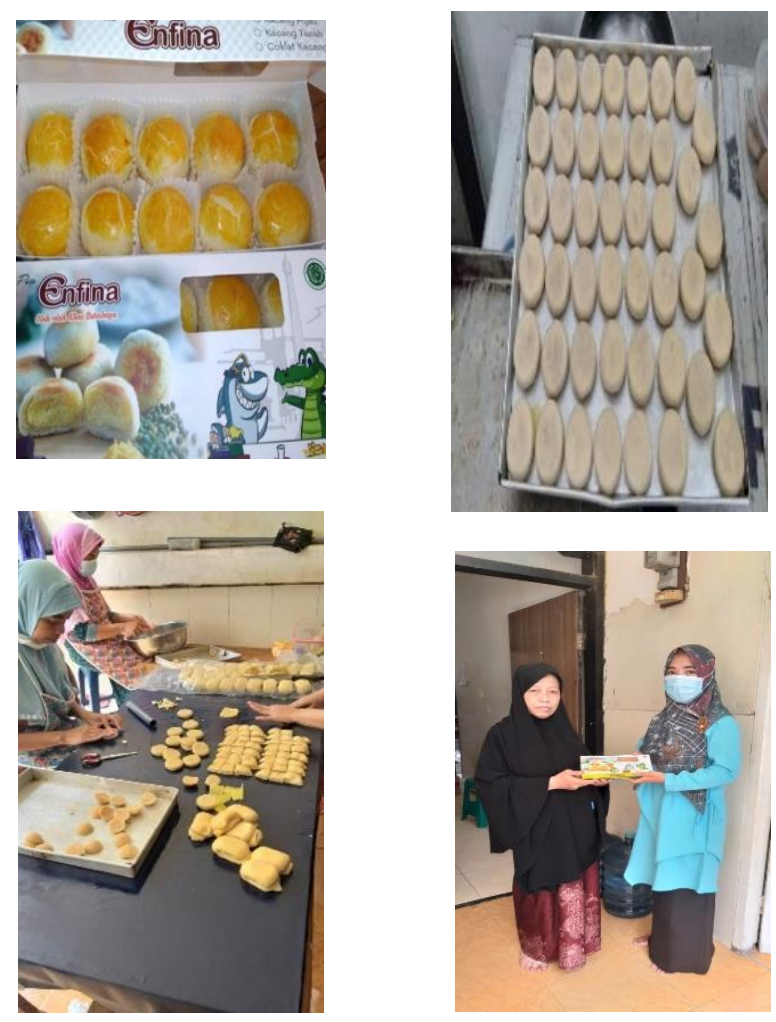

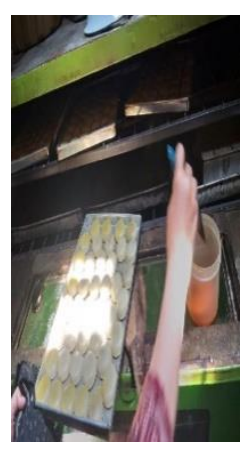

Gambar 1. Proses Produksi Pia Enfina

\section{KESIMPULAN}

Berdasarkan hasil dan pembahasan pada pengabdian ini dapat disimpulkan bahwa pengabdian diatas sebagian besar pelaku Usaha Mikro Kecil dan Menengah (UMKM) belum melakukan proses akuntansi secara lengkap, hanya terbatas pencatatan pemasukan, pengeluaran dan perhitungan laba. Pelaku usaha menganggap bahwa laporan akuntansi merupakan suatu yang sulit dipelajari serta memerlukan waktu dan biaya jika diterapkan. Walaupun sebagian besar pelaku usaha belum merasa perlu menerapkan akuntansi tetapi mereka sudah melakukan tahap awal dalam proses akuntansi yaitu mereka sudah mulai mengumpulkan bukti transaksi dan melakukan pencatatan transaksi meskipun secara praktis menurut pemahaman pelaku. Pelaku usaha masih mencampur catatan usaha dengan catatan keuangan pribadi, mereka menganggap semua yang diperoleh 
merupakan harta pribadi dan pengelola usaha merasa tanpa menerapkan akuntansi usaha mereka masih bisa berjalan dan berhasil, mereka melakukan pengambilan keputusan berdasarkan pengalaman.

\section{UCAPAN TERIMAKASIH}

Penulis mengucapkan terima kasih kepada Pimpinan Cabang

Muhammadiyah Gunung Anyar dan Lembaga Penelitian dan Pengabdian Kepada Masyarakat UMSurabaya yang telah mendukung terselenggara nya kegiatan pengabdian.

\section{DAFTAR PUSTKA}

Hardilawati, W. laura. (2020). Strategi Bertahan UMKM di Tengah Pandemi Covid-19. Jurnal Akuntansi Dan Ekonomika, 10(1), 89-98.

https://doi.org/10.37859/jae.v10i1. 1934

Hastuti, S. (2021). PENERAPAN COST REDUCTION STRATEGIES DI MASA PANDEMI COVID-19 PADA USAHA KECIL MENENGAH (UMKM) KOTA BOGOR (Studi pada Anggota UMKM di Komunitas Kefir Bogor). Jurnal Lentera Bisnis,
10(1),

78.

https://doi.org/10.34127/jrlab.v10i

1.394

Kusumawardhany, S. I. (2020).

Penerapan Akuntansi pada Usaha Mikro, Kecil, dan Menengah (UMKM) ( Studi pada UMKM Raja Eskrim ) di Kota Kediri. Jurnal Akuntansi Dan Perpajakan, 6(2), 76-81.

https://doi.org/10.26905/ap.v6i2.45 70

Mulyani, A. S., Nurhayaty, E., \& Miharja, K. (2019). Penerapan Pencatatan dan Laporan Akuntansi Pada Usaha Mikro Kecil Dan Menengah (UMKM). Jurnal Abdimas BSI: Jurnal Pengabdian Kepada Masyarakat, 2(2), 219226.

https://doi.org/10.31294/jabdimas. v2 2 . 5818

Novalien Carolina Lewaherilla, Huwae, V. E., \& Risambessy, A. (2021). STRATEGI PENGELOLAAN USAHA KECIL. 2(2), 338-342.

Pemerintah, P. N., Tentang Kemudahan, H., An, P., Pemberday, D., Koperasi, A., Usaha Mikro, D., Bab, D. M., Ketentuan, I., \& Pasal, U. (2021). Menetapkan PRES IDEN REPUBLIK INDONESIA-2- 
MEMUTUSKA N. 086507.

Rosita, R. (2020). Pengaruh Pandemi Covid-19 Terhadap Umkm Di Indonesia. Jurnal Lentera Bisnis, 9(2), 109. https://doi.org/10.34127/jrlab.v9i2. 380

Surjono, Ariwibowo, P., \& Nizma, M. (2021). Penerapan Standarisasi Laporan Keuangan Umkm Bagi Pengusaha Kecil Menengah Untuk Meningkatkan Kinerja Usaha Pada
Umkm Merta Jasa. Jurnal Lokabmas Kreatif: Loyalitas Kreatifitas Abdi Masyarakat Kreatif, 2(2), 28. https://doi.org/10.32493/jlkklkk.v2 i2.p28-34.11611

Wiyani, N. T., Akuntansi, A., Insani, B., Akuntansi, A., \& Insani, B. (2017). Penerapan Sak Etap Pada Penyusunan Laporan. 20(1), 2539. 